\title{
A CASE STUDY OF PV OUTPUT POWER DEGRADATION RATES IN OMAN
}

\author{
Mohamed Shaik Honnurvali ${ }^{1 *}$, Naren Gupta ${ }^{2}$, Keng Goh ${ }^{2}$, Tariq $\mathrm{Umar}^{3}$, Needa Nazeema ${ }^{4}$ \\ ${ }^{1}$ ECE Department, A'sharqiyah University, Al-Tabthi, Ibra, Sultanate of Oman \\ ${ }^{2}$ Electrical Department, Edinburgh Napier University, Edinburgh, United Kingdom \\ ${ }^{3}$ Civil Department, A’sharqiyah University, Al-Tabthi, Ibra, Sultanate of Oman \\ ${ }^{4}$ ECE Department, ITS Engineering Institute of Technology, New Delhi, India \\ "honnur.vali420@gmail.com,
}

\begin{abstract}
To meet the increase in peak electricity demand and to reduce fossil fuel emissions in Oman and as an initiative taken by the government, by $2030,15 \%(3000 \mathrm{MW})$ of the total energy $\operatorname{mix}(20,000 \mathrm{MW})$ should be generated from renewable energy resources like Solar and wind etc. It is crucial for the stakeholders and PV enthusiast to predict the return on investments and its performance in the local climatic conditions. In this paper, a case study has been presented where PV modules of different technologies, age and installed in different climatic conditions of Oman are studied. The results showed that the output power degradation for all modules is around $1.96 \% /$ year which is almost double compare to the European countries. Electrical analysis of different PV technologies showed that multi-crystalline silicon technology installed in hot and dry climate is degrading (around 2.54\%/year) faster, while thin-film technology (CdTe) has shown lowest degradation (average of $\mathbf{0 . 8 \%}$ /year) compare to any other PV technology. Furthermore, IR image analysis showed that presence of hot cells in PV modules are also a significant contributing factor in PV degradation rates. Severity of interconnect breakage (SIB) tests confirms the increase of the series-resistance of PV modules which is also a significant contributing factor for reduction in short-circuit current and thus PV maximum output power.
\end{abstract}

\section{Introduction}

According to recent world bank data, $85 \%$ of the total world population has gained access to electricity and $94 \%$ of the total urban population has access to electricity while in rural areas there has a significant increase in access to electricity from $61 \%$ (1990) to $73 \%$ (2014) [1]. However, focusing the production perspective, $66 \%$ of the total electricity demand in the world has been generated from the non-renewable energy resources such as coal, oil and gas. Similarly, $16 \%$ from the hydro and $10 \%$ from the nuclear. Remaining $8 \%$ is generated from a renewable source of energy such as Solar, Wind, Biomass etc. The Electricity consumption in the world has raised about $60 \%$ from 10,000 TWh (1990) to 22,000 TWh (2016) in the past decades [2].

Similar behaviour is also observed in the middle east countries as well, wherein the electricity consumption is increased to $950 \mathrm{TWh}$ (2016) from $200 \mathrm{TWh}$ (in 1990) with about five-fold increase since 1990. About $97.8 \%$ of the middle east countries energy production is generated through non-renewable energy sources such as coal, oil \& gas. Remaining $2.2 \%$ of the energy is generated from renewable sources [3].

Sultanate of Oman, a key part of Gulf Cooperative Council (GCC) countries covered about 309,500 sq. km (119,500 sq. miles) having about 2.9 million national populations has achieved $100 \%$ access to electricity according to world bank data. However, like other middle east countries, almost $96 \%$ of the total energy production is achieved with non-renewable energy sources. According to the recent 7-year statement issue (2016-2022) by the Oman Power and Water Procurement company (OPWP) has estimated that the peak electricity demand is expected to grow at around 9\% per year, from $5500 \mathrm{MW}$ in 2015 to $9500 \mathrm{MW}$ in 2022. Energy consumption is estimated to rise from about $27 \mathrm{TWh}$ in 2015 to $49 \mathrm{TWh}$ in 2022, with an annual growth rate of about $9 \%$ [4]. In order to meet peak demand and to reduce fossil emissions, the Oman Electricity Transmission Plan has stated that by $203015 \%$ of the total energy mix, approximately $3000 \mathrm{MW}$, has to be generated from renewable energy technologies (Solar and Wind) [5]. Considering this initiative and the investment in solar Photovoltaic (PV) power plants, it is important to understand the reliability and efficiency of the PV modules in the GCC climate conditions. The efficiency of the PV is measured by the amount of output power it is able to produce and hence, in evaluating the return of Investment (ROI) which is crucial for stakeholders, researchers, and manufacturers etc. The climate conditions experienced in GCC countries tend to be hotter (increase from $50^{\circ}$ to $55^{0}$ in summer) than the European countries. As a result, PV performance is affected due to these high temperatures and therefore experiences degradation faster than the European countries. It is crucial to estimate the effects of the hot climate conditions of GCC on the PV degradation in order to evaluate the efficiency of the PV modules in this region. Several PV degradation analysis has been conducted in other parts of the world. J. Kuitche et al. [6] have reported that the degradation rates of PV modules installed in grid-tied Arizona power plant were $0.8 \% /$ Year to $1.8 \% /$ Year for modules without hotspots. On the other hand with the hotspots, the degradation reported are as high as $4.9 \%$ year. Jordan et al. [7, 8] have reported that the mean degradation rates for crystalline silicon modules are $0.85 \% /$ year- $0.95 \% /$ year. The paper also states that the degradation rates in hot climate zones and raising installation from the ground level are high in some PV technology. Furthermore, surveys conducted by NISE (National Institute of solar energy, India) on the efficiency of different PV technologies (multi c-Si, a-Si and HIT) showed that multi cSi are degrading faster than thin film technologies $[9,10]$.

The current solar project capacity in Oman is about $9000 \mathrm{MW}$ of which $26 \%$ were installed in 2016 [4]. However, 
in order to move away from the non-renewable resources and restrict fossil fuel emissions, the government of Oman has shown enthusiasm towards renewable energies. One of the first and most important questions arises is the reliability of these resources under local climatic conditions. To answer the question, a case study has been conducted to understand the performance of PV in six different sites under different climate conditions with different PV technologies.

The results from the case study are classified mainly into four modes. Firstly, visual degradation effects such as discolouration and delamination are recorded and analysed their effect on the cause of the reduction in output power in the PV modules. Secondly, electrical degradation analysis emphasises factors such as climatic zones, different PV technologies and module age that contribute to the output power degradation rates. Thirdly, the interconnect breakage in PV modules which enhances the series resistance that leads to the reduction of the output power of PV modules. Finally, to understand the effect of hot climate, infrared (IR) images are taken for all modules and a concept called 'hot cells' is introduced to correlate their effect in output power degradation rates of $\mathrm{PV}$ modules.

\section{Case study Methodology}

A clear understanding of PV module degradation is possible by thorough analysis of each component of PV modules. The details of test bench setup and sites consider are available in [11] and technical characteristics of the PV modules and the key equipment's used in the case study are presented in Table 1.1 and 1.2. About 140 PV modules are considered in this case study. The sites considered are shown as black dots inFigure 1. Considering the internationally accepted Koppen-Geiger (K-G) climate classification system the majority of Oman falls under BWh category (Hot desert climates) which is termed as hot-and-dry regions in this paper. The average temperature and relative humidity (per year) observed in this region is around $49.2^{\circ} \mathrm{C}$ and $58 \%$. Two more zones are identified such as cold semi-arid climates (BSk) and hot semi-arid climates (BSh). The BSk region is termed as moderate climate in this paper, with an average temperature $\left(35.95^{\circ} \mathrm{C}\right)$ and relative humidity $(33.3 \%)$. Finally, the BSh region is labelled as hot-and- humid climate with an average temperature $\left(40.9^{\circ} \mathrm{C}\right)$ and relative humidity $(119.1 \%)$. The representation and mapping of these zones with the (K-G) climatic system are shown in the Figure 1. The first step of the task is to clean the modules with water to get rid of dust and then perform the following tests.

\subsection{Physical inspection}

Physical inspection of the modules was performed to consider the visible issues seen in different parts of a PV module. A visual inspection checklist, obtained from NREL [12] was completed. High-resolution images were taken for future references so as to be able to magnify the region of interest to analyse the defective area.

\subsection{Current-Voltage(I-V) Curve of PV}

The current-voltage (I-V) curve of PV modules is an important characteristic tool to evaluate the electrical performance of a PV module [13]. Two portable I-V tracers are used in the survey to record data of multiple PV modules in parallel. Apart from that, this equipment has additional accessories to measure the Plane of Array (POA), irradiance and module temperature. At least 3 sets of (I-V) curve readings are recorded for each module, at intervals of 2 minute. The relative humidity and ambient temperature are also recorded at the time of (I-V) measurement. If required, this data is used in spectral correction during STC translation of the field data [14].

\subsection{Interconnect Test}

Interconnect failure of PV modules can be detected by a device (Cell Line checker) from Togami Corporation [15]. In hot-and-dry climatic condition, it is reported that interconnect failure is one of the common failure modes observed in PV module [16]. The test comprises of two units a transmitter and receiver. In the receiver unit, the flashes of LEDs on a scale of 0-10 show the quality of the interconnect connection. Zero indicates no flash which indicates the failure of the interconnect ribbon.

\subsection{Infrared Images (IR)}

Hot spots are one of the prime factors for the degradation of PV modules [17]. In order to identify any hot spots formation in the surveyed sites, an IR camera is used to capture thermal images. All considered PV modules terminals are short-circuited when images are taken. To detect hot spot in the PV modules it is essential that the images should be taken at least when the irradiance is above $650 \mathrm{~W} / \mathrm{m} 2$. The IR images taken during the survey at irradiances below $650 \mathrm{~W} / \mathrm{m} 2$ are not considered for further analysis.

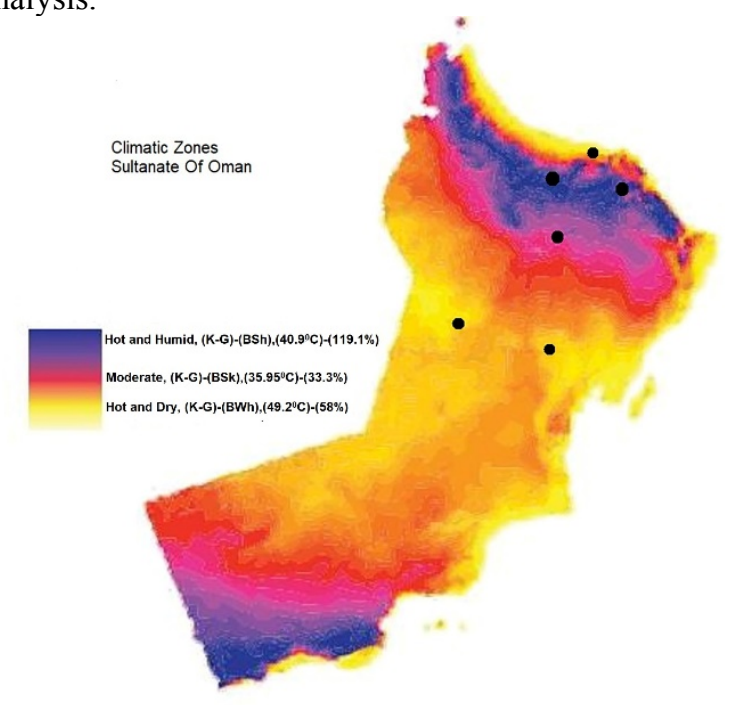

Figure 1. Climatic Zones of Oman based on (K-G) system with average temperatures and relative humidity per year. 
Table 1.1 Technical Characteristics of PV modules and key equipment's used.

\begin{tabular}{|c|c|c|}
\hline $\begin{array}{l}\text { PV modules } \\
\& \text { instruments }\end{array}$ & $\begin{array}{l}\text { Make \& } \\
\text { model number }\end{array}$ & Specifications \\
\hline Monocrystalline & STP240S-20/Wd & $\begin{array}{l}\text { Optimum Operating voltage(Vmp):30.2V; Optimum Operating current (Imp): } \\
\text { 7.95A; Open Circuit Voltage (Voc): } 37.2 \mathrm{~V} \text {; Short Circuit current (Isc): } 8.43 \mathrm{~A} \text {; } \\
\text { maximum power at STC (Pmax): } 240 \mathrm{~W} \text {; Module efficiency: } 14.8 \% \text {; operating } \\
\text { module temperature: }-40^{\circ} \mathrm{C} \text { to }+85^{\circ} \mathrm{C} \text {; Power Tolerance: } 0 /+5 \% \text {. }\end{array}$ \\
\hline
\end{tabular}

Centsys 200W Optimum Operating voltage(Vmp):24.6V; Optimum Operating current (Imp): 8.13A; Open Circuit Voltage (Voc): 30V; Short Circuit current (Isc): 8.56A; maximum power at STC (Pmax): 200W; Module efficiency: 15.3\%; operating module temperature: $-40^{\circ} \mathrm{C}$ to $+85^{\circ} \mathrm{C}$; Power Tolerance: $\pm 3 \%$.

RNG-100D Optimum Operating voltage(Vmp):18.9V; Optimum Operating current (Imp): 5.29A; Open Circuit Voltage (Voc): 22.5V; Short Circuit current (Isc): 5.75A; maximum power at STC (Pmax): 100W; Module efficiency: 15.47\%; operating module temperature: $-40^{\circ} \mathrm{C}$ to $+80^{\circ} \mathrm{C}$; Power Tolerance: N/A.

Centsys 80W Optimum Operating voltage(Vmp):18V; Optimum Operating current (Imp): 4.44A; Open Circuit Voltage (Voc): 22V; Short Circuit current (Isc): 4.85A; maximum power at STC (Pmax): $80 \mathrm{~W}$; Module efficiency: 13.05\%; operating module temperature: $-40^{\circ} \mathrm{C}$ to $+85^{\circ} \mathrm{C}$; Power Tolerance: $\pm 3 \%$.

\begin{tabular}{lll}
\hline Multicrystalline & SLK60P6L & Optimum Operating voltage(Vmp): 29.57V; Optimum Operating current (Imp): \\
& 8.20A; Open Circuit Voltage (Voc): 37.2V; Short Circuit current (Isc): $8.79 \mathrm{~A} ;$ \\
& maximum power at STC (Pmax): $240 \mathrm{~W} ;$ Module efficiency: $14.8 \%$; operating \\
& module temperature: $-40^{\circ} \mathrm{C}$ to $+85^{\circ} \mathrm{C}$; Power Tolerance: $\pm 3 \%$.
\end{tabular}

JW-120P Optimum Operating voltage(Vmp): 17.6V; Optimum Operating current (Imp): 6.82A; Open Circuit Voltage (Voc): 21.4V; Short Circuit current (Isc): 7.36A; maximum power at STC (Pmax): $120 \mathrm{~W}$; Module efficiency: 12.9\%; operating module temperature: $-40^{\circ} \mathrm{C}$ to $+85^{\circ} \mathrm{C}$; Power Tolerance: $\pm 10 \%$.

\begin{tabular}{|c|c|c|}
\hline $\begin{array}{l}\text { Amorphous } \\
\text { silicon }\end{array}$ & U-SA110 & $\begin{array}{l}\text { Optimum Operating voltage(Vmp): } 53.5 \mathrm{~V} \text {; Optimum Operating current (Imp): } \\
\text { 2.04A; Open Circuit Voltage (Voc): } 71 \mathrm{~V} \text {; Short Circuit current (Isc): } 2.5 \mathrm{~A} \text {; } \\
\text { maximum power at STC (Pmax): } 110 \mathrm{~W} \text {; Module efficiency: } 9 \% \text {; operating module } \\
\text { temperature: }-20^{\circ} \mathrm{C} \text { to }+80^{\circ} \mathrm{C} \text {; Power Tolerance: }-5 \% \text { to }+10 \% \text {. }\end{array}$ \\
\hline $\begin{array}{l}\text { CdTe } \\
\text { Thinfilm }\end{array}$ & GE-cdTe83 & $\begin{array}{l}\text { Optimum Operating voltage(Vmp): 75V; Optimimum Operating current (Imp): } \\
\text { 1.10A; Open Circuit Voltage (Voc): } 95 \mathrm{~V} \text {; Short Circuit current (Isc): } 1.25 \mathrm{~A} ; \\
\text { maximum power at STC (Pmax): } 83 \mathrm{~W} \text {; Module efficiency: } 11.5 \% \text {; operating } \\
\text { module temperature: N/A; Power Tolerance: } \pm 10 \% \text {. }\end{array}$ \\
\hline
\end{tabular}

Table 1.2 Technical Characteristics of PV modules and Key equipment's used.

\begin{tabular}{|c|c|c|}
\hline $\begin{array}{l}\text { PV modules } \\
\text { \& Instruments. }\end{array}$ & $\begin{array}{l}\text { Make \& } \\
\text { Model No. }\end{array}$ & Specifications. \\
\hline $\begin{array}{l}\text { I-V curve } \\
\text { Tracer }\end{array}$ & $\begin{array}{l}\text { MECO- } \\
9018 \mathrm{BT}\end{array}$ & $\begin{array}{l}\text { Voltage Range (\& Accuracy): 0-1000 V DC, }( \pm 1 \% \pm(1 \% \text { of Voc } \pm 0.1 \mathrm{~V}) \\
\text { Current Range (\& Accuracy): 0.1-12 A DC, }( \pm 1 \% \pm(1 \% \text { of Isc } \pm 9 \mathrm{~mA}) \\
\text { Irradiance Sensor Range (\& Accuracy): 0-2000 W/m2, }( \pm 3 \%) \\
\text { Temperature Measurement (\& Accuracy):-22 to } 85^{\circ} \mathrm{C},( \pm 1 \%)\end{array}$ \\
\hline $\begin{array}{l}\text { Infrared } \\
\text { Camera }\end{array}$ & EasIR-4 & $\begin{array}{l}\text { Temperature Range: }-20^{0} \mathrm{C} \text { to } 350^{\circ} \mathrm{C} \\
\text { Thermal Sensitivity: }<0.1^{\circ} \mathrm{C} @ 30^{\circ} \mathrm{C} \\
\text { Detector Type: UFPA Microbolometer, }(160 \times 120 \text { Pixels, } 25 \mu \mathrm{m}) \\
\text { Accuracy: } \pm 2 \% \text { of reading or } 2^{0} \mathrm{C} \text {. }\end{array}$ \\
\hline $\begin{array}{l}\text { Cell Line } \\
\text { Checker }\end{array}$ & $\begin{array}{l}\text { Togami SPLC- } \\
\text { A-Y1 }\end{array}$ & $\begin{array}{l}\text { Voltage range: } 15 \mathrm{~V} \text { DC }-1000 \mathrm{~V} \text { DC (Magnetic field mode), } 0-1000 \mathrm{~V} \text { DC } \\
\text { (Electric Field mode) }\end{array}$ \\
\hline
\end{tabular}




\begin{tabular}{|c|c|c|}
\hline $\begin{array}{l}\text { Insulation } \\
\text { Resistance } \\
\text { Tester }\end{array}$ & FLUKE 1550C & $\begin{array}{l}\text { Insulation test voltage: } 250 \mathrm{~V} / 500 \mathrm{~V} / 1000 \mathrm{~V} / 2500 \mathrm{~V} / 5000 \mathrm{~V} \\
\text { Leakage current measurement range : } 1 \mathrm{nA}-2 \mathrm{~mA}\end{array}$ \\
\hline $\begin{array}{l}\text { DC Power } \\
\text { Supply }\end{array}$ & $\begin{array}{l}\text { GWInstek } \\
\text { PSW 160-14.4 }\end{array}$ & $\begin{array}{l}\text { Rated Output Voltage: } 160 \mathrm{~V} \mathrm{dc} \\
\text { Rated Output Current: } 14.4 \mathrm{~A} \mathrm{dc}\end{array}$ \\
\hline Digital camera & Nikon D3200 & $\begin{array}{l}\text { Effective Pixels: } 24.2 \text { Million } \\
\text { Image sensor: } 23.2 \text { x } 15.4 \mathrm{~mm} \text { CMOS sensor }\end{array}$ \\
\hline Colorimeter & $\begin{array}{l}\text { Testronix } \\
\text { TP110 }\end{array}$ & $\begin{array}{l}\text { Light Source: D65 } \\
\text { Illumination/observation system: } 8^{0} \text { illumination angle/ diffuse viewing }\end{array}$ \\
\hline
\end{tabular}

\section{Visual degradation Observations}

The details of the number of inspected modules based on climate and other parameters are shown in Table 2. Among the total 140 modules, approximately $7.6 \%$ (10 modules) were discarded as the degradation observed in these modules increased more than $6 \%$ /year, which are considered as faulty ones and not considered in further analysis.

PV modules degradation becomes visually evident even before electrical parameters are evaluated. Analysis of the visual degradation is crucial in determining the degradation of electrical parameters of PV modules such as short-circuit current $\left(I_{s c}\right)$, power degradation $\left(P_{\max }\right)$ and fill factor $(\mathrm{FF})$. Different parts of PV modules degrade in many ways, first, the encapsulate of PV turns into yellow or brown colour when

Table 2. Case Study Site Summary

\begin{tabular}{llcr}
\hline Climatic & Number of & $\begin{array}{c}\text { Number of } \\
\text { Zodules }\end{array}$ & $\begin{array}{r}\text { PV Tech } \\
\text { distrib }\end{array}$ \\
& $\begin{array}{l}\text { Sites } \\
\text { considered }\end{array}$ & \begin{tabular}{c} 
considered \\
\hline
\end{tabular} & \\
\hline
\end{tabular}

$\begin{aligned} & \text { Hot and } \\ & \text { Dry }\end{aligned}$
$\begin{array}{lll}\text { Mono-C-si (21 } \\ \text { si (30), a-si (1 }\end{array}$

\begin{tabular}{|c|c|}
\hline Moderate & 1 \\
\hline $\begin{array}{l}\text { Hot and } \\
\text { humid }\end{array}$ & 2 \\
\hline Total & 6 \\
\hline
\end{tabular}

exposed to sunlight and high temperature for long period of time. It also loses adhesion and gets delaminated due to humidity and metallization corroding due to high temperatures [19]. There are several visual degradations observed in PV modules around the world. However, in this study, two major visual degradations were seen on site. First is the discolouration of the encapsulate and second, the delamination on the front side of the PV modules, apart from these snail trails and discolouring of metallization is also observed. However, due to less frequency of occurrence, we did not consider it for further analysis in our study.

Discoloration of encapsulating is one of the major cause of the reduction of short-circuit current $\left(I_{s c}\right)$ and Power degradation (Pmax). Discoloration of the encapsulation mainly occurs due to certain additives and it is possible to reduce its effect and/or avoid it by proper choice of additives as shown in [20]. Discoloration observed in this study is shown in Table 3 . The table shows the percentage of modules affected by the respective climatic zone and age group, followed by the number of samples considered (in brackets). One can observe from the table that the discolouration frequency is less in newer age modules, on the other hand, it is much higher in the aged modules ( $>$ five years). Modules in all the zones (Hot-and-dry, Moderate and hot-and-humid) have shown discolouration upon ageing. It is also observed that some PV modules started to discolour in less than two years which raises question regarding the quality of the materials being used.

Apart from discolouring of encapsulation, the other

Table 3. Percentage of all modules affected by

discoloration of encanculate

Table 4. Percentage of all modules affected by front-side delamination

\begin{tabular}{llll}
\hline Climatic & \multicolumn{3}{c}{ Age Groups (in years) } \\
\cline { 2 - 4 } Zone & $0-2$ & $2-5$ & $>5$ \\
\hline & & & \\
Hot-and-dry & $6 \%(32)$ & $8 \%(20)$ & $90 \%(10)$ \\
Moderate & $0 \%(8)$ & $2 \%(9)$ & $45 \%(9)$ \\
Hot-and-humid & $6 \%(25)$ & $48 \%(10)$ & $88 \%(7)$ \\
All Climates & $\mathbf{5 \% ( 6 5 )}$ & $\mathbf{1 7 \% ( 3 9 )}$ & $\mathbf{7 4 \% ( 2 6 )}$
\end{tabular}

\section{(Comparative)}

visual degradation noticed is front-side delamination. This mainly occurs due to loss of adhesion between two layers of the module laminate. The occurrence of delamination on front-side enhances reflection losses, thus leading to the reduction of short-circuit current (Isc) and Power degradation (Pmax) i.e. output power of the module. Table 4. Provides the observations of front-side delamination in this case study.

Delamination and discolouration have occurred less in newer modules. Higher percentage of older module (age group $>5$ ) suffers in hot-and-dry and hot-and-humid zones. It is also noticed that under hot-and-humid climate zone, the modules with age 2-5, tend to suffer compare to other climate zones. Modules in moderate climatic zone seem to be least affected by front-side delamination, which indicates that the temperature parameter plays a major role in the occurrence of 
delamination. This is expected from theory, that the adhesive properties in polymer reduce with respect to higher temperatures. Furthermore, to analyse the effect of these visual defects with the module performance, a correlation is performed for the visual defects seen on site (i.e. discolouration and delamination) with the degradation in the electrical parameter, such as short-circuit current, $\mathrm{I}_{\mathrm{sc}}$. Subsequently, the reduction of $\mathrm{I}_{\mathrm{sc}}$ leads to the reduction in the $\mathrm{P}_{\max }$ output power deliverable [11].

Solar irradiation arrives in PV cells is reduced due to discolouration and delamination in the encapsulation, therefore decreasing the short-circuit current of the PV module. To correlate the visual defects observed in this case study with respect to electrical performance, a composite index has been developed and is referred in this paper as Discoloration and Delamination Index (DDI). DDI is given by the mathematical relation shown in equation (1). Where Degree of discolouration $=1$ for light discolouration and 2 for dark discolouration; Degree of Delamination $=2$ (assuming the same impact on cell's performance as dark discolouration); normalizing factor $=4$ (based on the maximum possible value of the numerator). The value of DDI can vary between 0 and 1 , where 1 represents maximum possible degradation and 0 represents no degradation. (a)

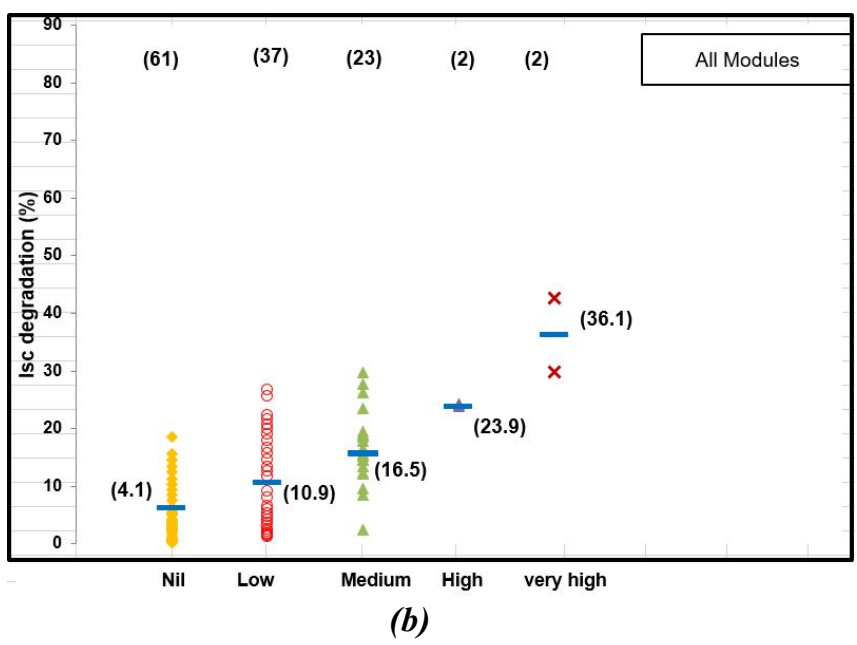

Figure 2. Samples of DDI Category

(a) PV Sample of (i) medium; (ii) high; (iii) very high degradation.

(b) $I_{s c}$ total reduction for different DDI category.

$$
D D I=\frac{\text { Degree of discoloration } \times \text { Discolored cell area }+ \text { Degree of delamination } \times \text { Delaminated cell area }}{\text { Normalizing factor }(=4)}
$$

Based on the DDI value, the modules have been grouped into five categories as shown in table 5. Examples sample of modules with medium (a), high (b) and very high degradation (c) of DDI values are shown in Figure 2(a). Short-circuit current $\left(\mathrm{I}_{\mathrm{sc}}\right)$ reduction for different DDI categories is shown in Figure 2(b). The mean values of $I_{s c}$ reduction are indicated with the blue horizontal bar. The mean value is used as it serves as an estimator of central tendency. From Figure 2(b), It is noticed that the mean short-circuit current reduction shows good correlation to the respective DDI categories since it increases with the increase in the DDI category.

Table 5. DDI category based on DDI Value

\begin{tabular}{lccccc}
\hline $\begin{array}{l}\text { DDI } \\
\text { Value }\end{array}$ & 0 & $0-0.25$ & $0.25-0.5$ & $\begin{array}{l}0.5- \\
0.75\end{array}$ & $0.75-1$ \\
\hline $\begin{array}{l}\text { DDI } \\
\text { Category }\end{array}$ & Nil & Low & Medium & High & $\begin{array}{l}\text { Very } \\
\text { high }\end{array}$
\end{tabular}

The results observed above raises a crucial question about the module quality from the manufacturers. It is important for the modules to undergo relevant robust tests and pass the international standard certifications to ensure the quality and performance in long-term operation.

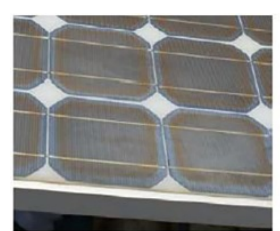

(i)

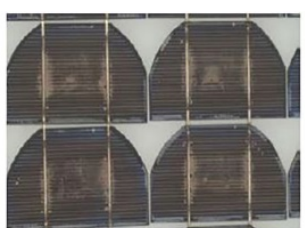

(ii)

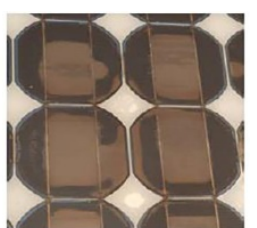

(iii)

\section{Electrical Degradation Analysis}

Accurate prediction of power generated over time is crucial to understand the efficiency of PV modules on the field. To evaluate this, it is essential to know mean degradation rate of the modules in percentage power reduction per year. I-V curves of different modules in case study are translated to standard test conditions (STC) as shown in previous work [11]. This acquired data is used to compare its current-day performance with its initial

$$
\% P_{\text {max }} \text { diff }=\frac{\left(P_{\text {max }, \text { rated }}-P_{\text {max }, \text { measured }}\right)}{P_{\text {max }, \text { rated }}} \times 100
$$

performance during the time of installation. The modules considered in this case study are installations from the year 2011-2017. Therefore, it is not possible to know the initial performance of the older modules during their time of installation. Instead name plate ratings/datasheets from online sources are considered as initial performance factor. As a result, an uncertainty is created in the degradation rates calculation due to the tolerance band (usually $\pm 10 \%, \pm 5 \%$ and $\pm 3 \%$ ) as provided by the manufacturer. The difference in the $\mathrm{P}_{\max }$ degradation rates is calculated using the equation (2). Figure 3(a) shows the observed $\mathrm{P}_{\max }$ difference in percentage per year. As an indicator, the tolerance values of $\pm 10 \%$ and $\pm 5 \%$ are shown with dashed lines. An average $\mathrm{P}_{\max }$ difference from the measured values and the rated values for the entire period is observed to be at $1.33 \%$ with a standard deviation of $\pm 5.88 \%$. The percentage degradation rates of electrical parameters of PV modules such as output power $\left(P_{\max }\right)$, shortcircuit current $\left(I_{s c}\right)$, open circuit voltage $\left(V_{o c}\right)$ and fill factor 
(FF) under the three climatic zones is shown in Figure 3(b). It can be clearly seen that the $I_{s c}$ degradation is high in both the hot climate zones making it the largest contributor in the $P_{\max }$ degradation. As discussed in Section 3 (visual degradations) browning of the EVA encapsulate due to high temperatures is the major cause of reduction in $I_{s c}$. In moderate climatic zone the major contributor in $\mathrm{P}_{\max }$ degradation is due to increase in fill factor $(F F)$, caused by an increase in series resistance due to poor manufacturing quality of the PV modules. The histogram of the evaluated degradation rates of the inspected modules is shown in Figure 3 (c). The mean degradation rate observed for the all considered modules is $1.96 \% /$ year with a median of $2 \% /$ year. It can be seen fromFigure 3 that wide variability of distribution is seen in the degradation

rates. Around $20 \%$ of the inspected modules show the degradation rates below $1 \%$ year, and the most regularly occurring degradation rate is $1.5 \%$ /year (mode of the histogram). It can also be observed from the histogram that the number of modules showing degradation rates more than $2.5 \% /$ year is also much higher. These observations have lead to a conclusion that several factors are contributing to these high degradation rates such as climatic factors, quality of the material, installation type and size of the system etc.
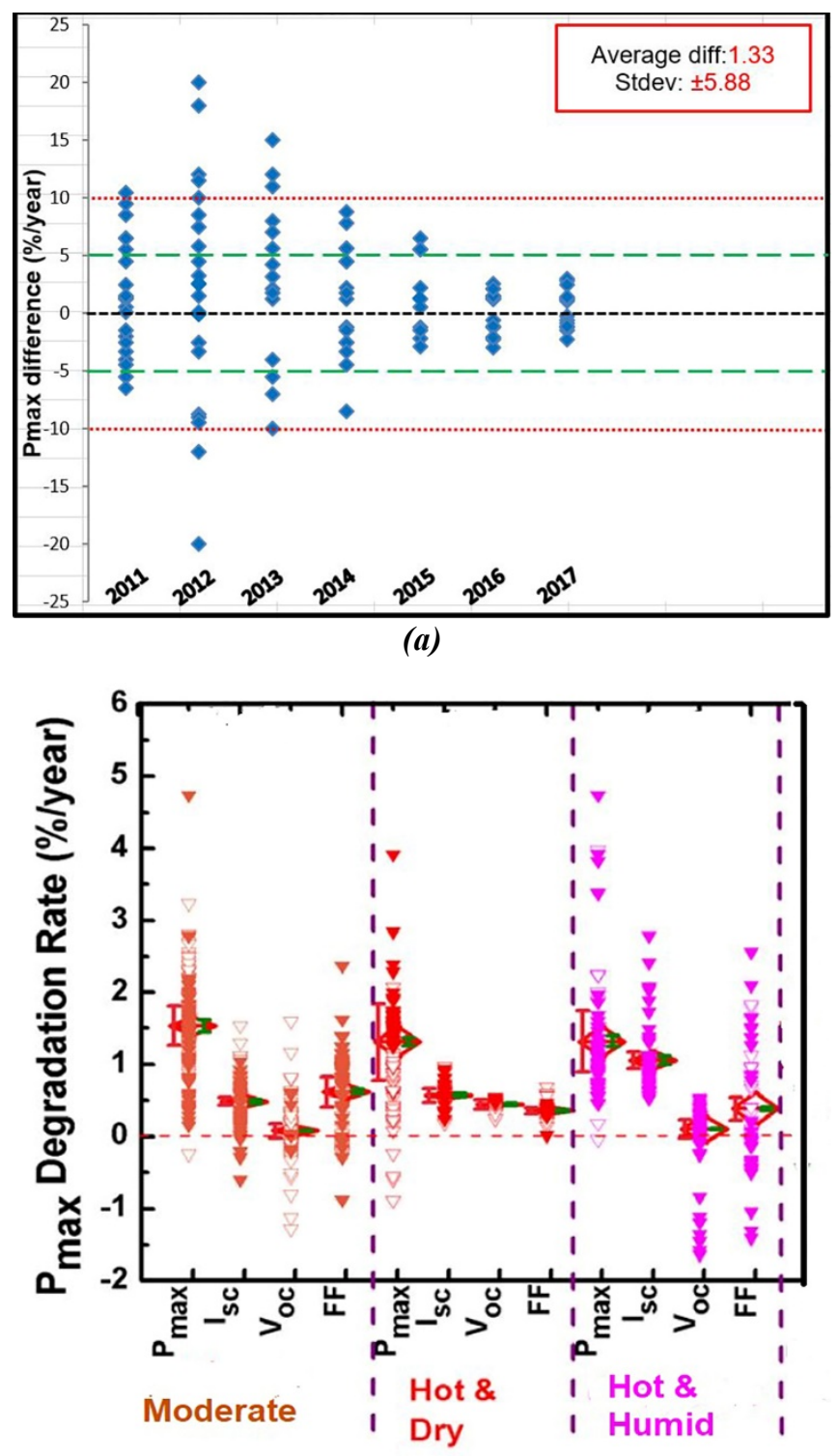

(b)

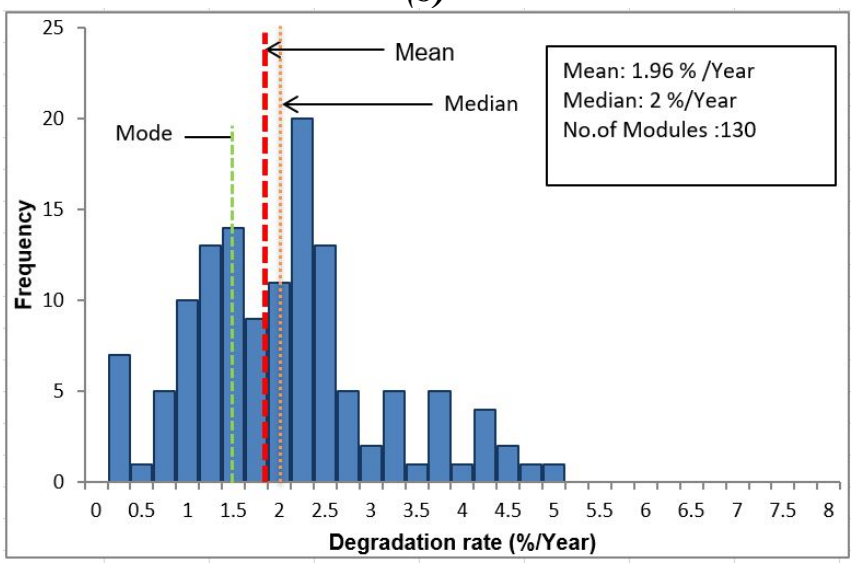

(c)

Figure 3. Distribution of various parameters of all modules.

(a) $P_{\max }$ difference between measured and rated values.

(b) Electrical parameter distribution with respect to three climatic zones.

(c) Histogram of $P_{\text {max }}$ degradation.

To analyse and understand the distribution better, the degradation rates of all observed modules are separated based on climatic region and the PV technology from the manufactures. The manufacturers, which have been anonymised, are referred to numbers (1-6) as shown in Figure 4(a). The three different climatic zones seen along with the sites (A-E) are shown in Figure 4(a). There are six sites being considered in this study and three sites have hot-and-dry climatic conditions. Due to a lesser modules inhot-and-dry sites, the data has been merged from three sites to two sites as shown in Figure 4(a). One can observe that the degradation rate of output power $\left(P_{\max }\right)$, in hot-and-dry climate was very high (i.e. $>5 \% /$ year) and also has variable dispersion rate. The reason could be due to visual degradations observed on site which are discussed in earlier section. The results of a study conducted by Tamizhmani [21] also showed that the hot zones tend to degrade at much higher rate than other climatic zones in the USA. On the other side, the degradation rates seen in other climatic regions are lower and shows loosely bound degradation rates. The data is colour coded based on the climatic regions as shown in Figure 4(a).

The power degradation rates based on PV module technology and climate is shown in Figure 4(b). Multi C-Si technology in the hot-and-dry zone has seen a significant impact on its power degradation (i.e. mean degradation rate is $2.54 \%$ /year) while in hot-and-humid zone Mono-C-Si has seen the high impact (1.52\%/year). The best choice in both the climatic zones seems to be thin film technologies (a-Si and $\mathrm{CdTe}$ ) whose rates were observed to be $<1.0 \% /$ year which agrees with the observations presented in $[7,8]$ by Jordan et al. Among the thin-film modules, from Figure 4(b), it shows that the CdTe modules are degrading the least and has the best performing. However, there is a caution on such conclusion as the number of surveyed modules are less. 


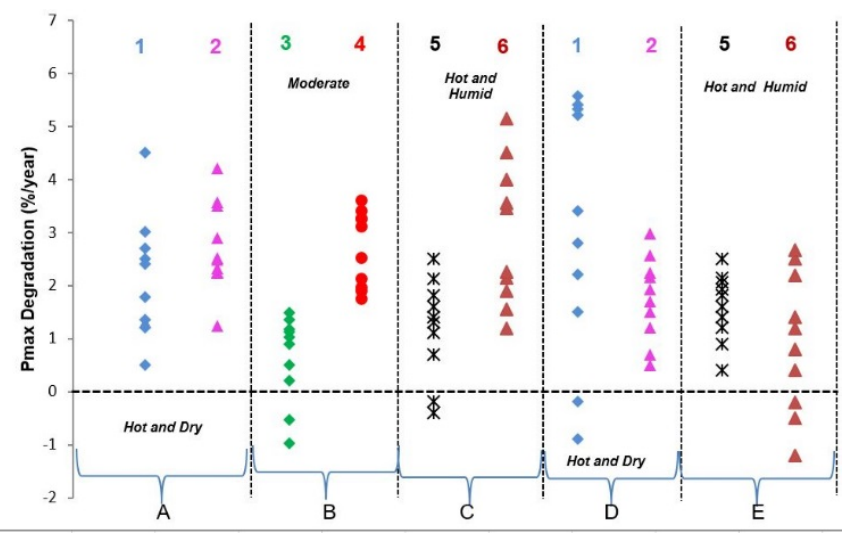

(a)

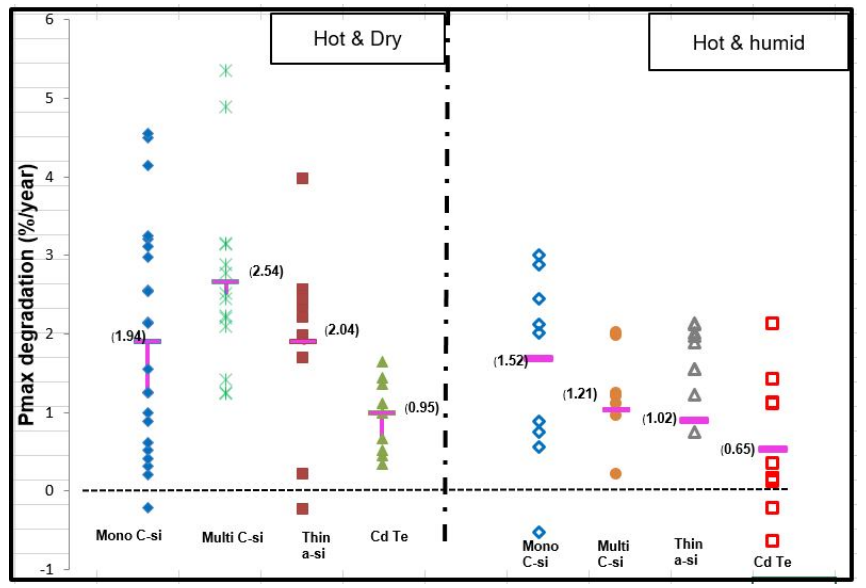

(b)

Figure 4. Power degradation of all modules

(a) Climatic wise, Manufacturer, Site wise (Pmax) degradation rates, 1 to 6 show different manufactures seen in different sites.

(b) based on PV technology and climatic zone.

\section{Interconnect Breakage Test Analysis}

The generated PV current is transferred to the load by the interconnects present in the PV module. Normally a PV module has 3 or 4 interconnects in each cell, which provides redundancy if any interconnect is faulty. However, even a breakage in single interconnect causes the flow of current through another interconnects leading to the increase of series resistance in the PV module. , It further reduces the fill factor (FF) and thus the output power $\left(P_{\max }\right)$. Interconnect breakage test has been conducted using a cell line checker. The breakages identified in the case study are classified into two types: 1. Point breakage (if the breakage occurs at certain points in the interconnect busbars) and 2. Line breakage (if the breakage occurs at certain points in the interconnect

$$
S I B=\frac{\text { No.of cells effected }}{\text { Total No.of cells in module }}
$$

busbars) as shown inFigure 5. Severity of interconnect breakage (SIB) is given by the equation (3). Table 6 shows the percentage of cells affected by interconnecting breakage based on age and climatic zone. It is evident from the table 6 that the modules in hot-and-humid $(\mathrm{H} \& \mathrm{H})$ are highly affected than the modules which are present in other climatic zones. It is mostly due to corrosion found in interconnects which occurs mostly in humid environments. The next likely affected modules lie in hot-and-dry ( $\mathrm{H} \& \mathrm{D})$ zone. A correlation is performed to link the severity of interconnect breakage with the series resistance of the PV modules. The series resistance of a module is obtained by considering the inverse slope of I-V curve near the open circuit voltage point (the current will be nearly zero at this point).

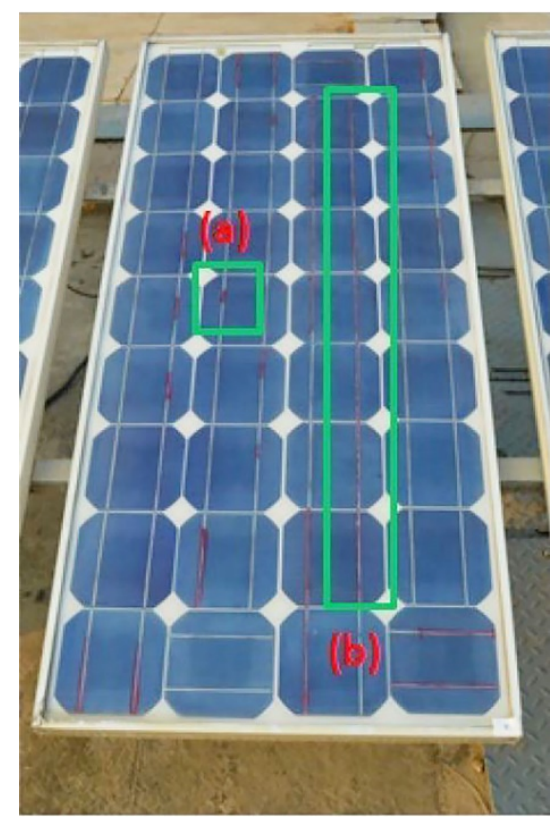

Figure 5. Interconnect failure points (a) Point breakage (b) line breakage.

Table 6. Percentage of all modules affected by interconnect breakage in different climate and age groups.

\begin{tabular}{lrrl}
\hline Age & \multicolumn{3}{c}{ Climatic Zones } \\
\cline { 2 - 4 } Group in yrs. & H \& D & Moderate & H \& H \\
\hline & & & \\
$0-2$ & $19 \%(32)$ & $0 \%(8)$ & $15 \%(25)$ \\
$2-5$ & $4 \%(20)$ & $11 \%(9)$ & $70 \%(10)$ \\
$>5$ & $40 \%(10)$ & $0 \%(9)$ & $80 \%(7)$ \\
All Ages & $\mathbf{1 8 \% ( 6 2 )}$ & $\mathbf{4 \% ( 2 6 )}$ & $\mathbf{3 9 \% ( 4 2 )}$ \\
(Comparative) & & &
\end{tabular}

Figure 6(a). shows the correlation of SIB with the series resistance. It could be observed from Figure 6(a) that as the SIB increases the series resistance of the module also increases which reduces the fill factor $(\mathrm{FF})$ as a result, the output power $\left(P_{\max }\right)$ also decreases. It is also observed that in an earlier section (Electrical degradation analysis) that the hot zone climate modules have experienced high degradation that other climatic regions. This is properly justified since the interconnect breakage is seen mostly in hot zones (i.e. both $\mathrm{H}$ \& D, $\mathrm{H} \& \mathrm{H})$. Figure 6(b) shows the correlation of $\left(P_{\max }\right)$ degradation rate (\%/year) with SIB for all modules. It could be observed that the output power degradation rate enhances with the increase in the SIB. 


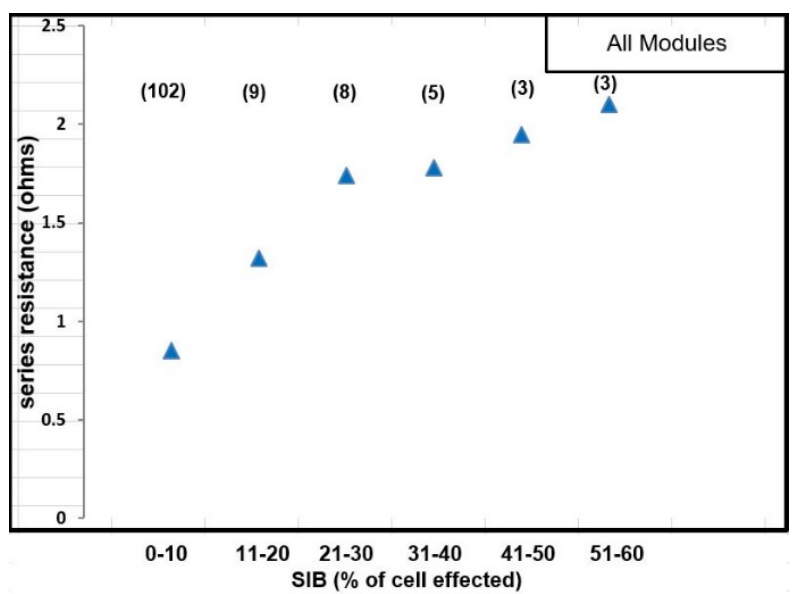

(a)

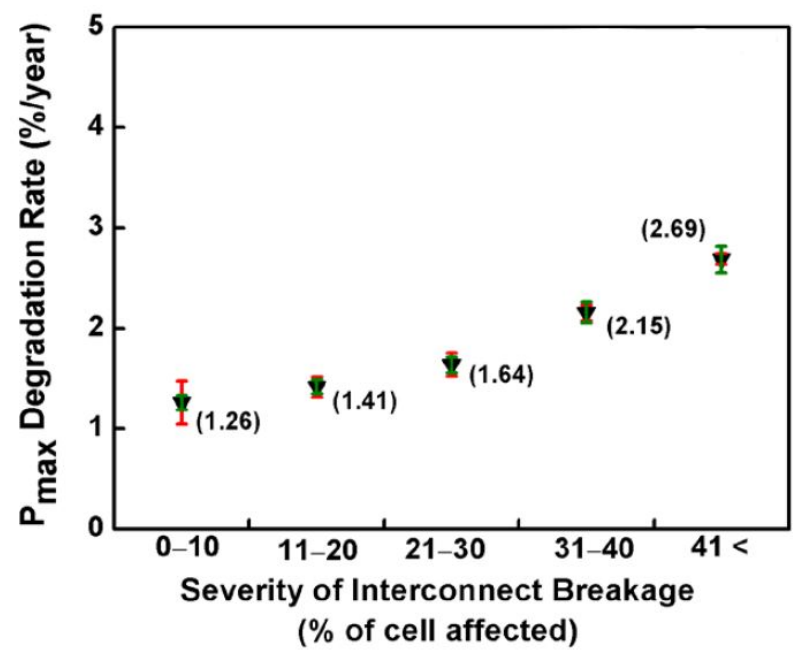

(b)

Figure 6. Correlation graphs

(a) Correlation of average values of series resistance with $S I B$

(b) Correlation of $P_{\max }$ degradation with SIB for all modules.

\section{IR Data Analysis}

IR image of each PV module under normal operating condition was taken by short-circuiting the module terminals. Each PV module was short-circuited for at least three to five minutes before taking the IR picture. Hotspots identified in such case are considered a worst-case scenario since, under normal MPPT operation, the hotspots obtained are less severe. The histogram of the module temperature of 'All' modules is shown in Figure 7(a) and the maximum cell temperatures are shown in Figure 7(b). The lowest PV module temperature recorded was $18^{\circ} \mathrm{C}$ (in the moderate zone) and the highest was $88.8^{\circ} \mathrm{C}$ (in $\mathrm{H} \& \mathrm{D}$ ) with the average about $60^{\circ} \mathrm{C}$. the highest cell temperature recorded was $171^{\circ} \mathrm{C}$, and the temperatures above $100^{\circ} \mathrm{C}$ were seen in around 9 modules. The IR images taken for different modules are at different times of a day, and on different days and sites, ambient conditions for the IR images have varied considerably. Therefore, it is certainly to translate(normalize) the evaluated data to the standard condition so that resemblance can be made between the obtained data in this case study. The temperatures are normalized to the STC condition $1000 \mathrm{~W} / \mathrm{m}^{2}$ and $40^{\circ} \mathrm{C}$, by the equation given in (4) $[22,23]$ : where, $T_{\text {normalised }}$ is normalised temperature, $T_{\text {measured }}$ is

$$
T_{\text {normalised }}=40+\frac{\left(T_{\text {measured }}-T_{\text {ambient }}\right) \times 1000}{\text { Irradiance }}
$$

module temperature (from IR image) and $T_{\text {ambient }}$ is ambient temperature at site. Further module $\Delta T$ is calculated by the equation (5), where $T_{\text {maxcell,norm }}$ is the normalised maximum cell temperature of the module and $T_{\text {module,norm }}$ is the normalised modal temperature of the module. The module $\Delta T$ gives the mismatch between the different cell

$$
\text { module } \Delta T=T_{\text {maxcell,norm }}-T_{\text {module,norm }}
$$

temperatures of the PV module. Earlier research [24] have reported that a hot cell, having $9^{\circ} \mathrm{C}$ higher than the surrounding hot cells, will lead to the decrease of around $20 \%$ in $I_{m p}$ (maximum power point current), which again corresponds to the decrease in output power by $15 \%$. Therefore, The modules whose normalised module $\Delta T$ higher than $10^{\circ} \mathrm{C}$ are considered as 'Hot cells' in this case study.

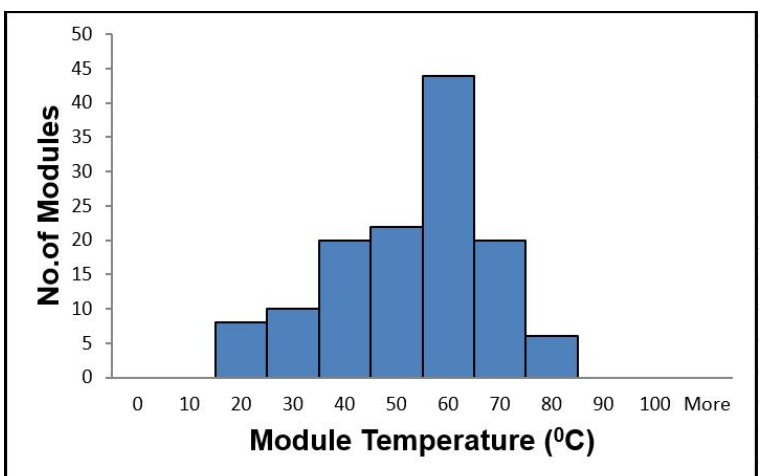

(a)

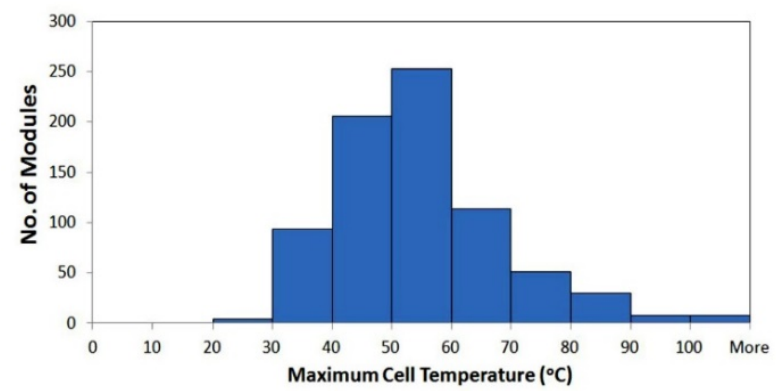

(b)

Figure 7. Temperatures inspected in the case study

(a) All Module temperature

(b) Maximum cell temperatures

Further, the three climate zones are classified into two climate zones (Hot Zone and Non-Hot zone) for easier analysis to arrive for a brief summary. A correlation has performed to analyse the effect of these 'Hot cells' with the output power degradation. From table 6. One can see the effect of 'Hot cells' on the output power degradation rates. Although the sample considered is less to provide definitive degradation rates for the two zones, but the trend seems to be same that is the 'Hot 
cells' degrade much faster than the modules without 'Hot cells' in both climatic zones. Figure 8 . Shows the correlation

Table 7. Influence of Hot cells on Power degradation of PV modules.

\begin{tabular}{|c|c|c|c|c|}
\hline \multirow{2}{*}{$\begin{array}{l}\text { Average of } \\
\text { Many } \\
\text { Samples. }\end{array}$} & \multicolumn{2}{|c|}{ Hot Zone } & \multicolumn{2}{|c|}{$\begin{array}{l}\text { Non-Hot } \\
\text { Zone } \\
\end{array}$} \\
\hline & $\begin{array}{l}\text { Without } \\
\text { Hot } \\
\text { cells }\end{array}$ & $\begin{array}{l}\text { With } \\
\text { Hot } \\
\text { cells } \\
\end{array}$ & $\begin{array}{l}\text { Without } \\
\text { Hot } \\
\text { cells }\end{array}$ & $\begin{array}{l}\text { With } \\
\text { Hot } \\
\text { cells } \\
\end{array}$ \\
\hline $\begin{array}{l}\text { Power } \\
\text { degradation } \\
\text { rate }(\% / \text { year })\end{array}$ & 1.38 & 2.01 & 1.38 & 1.65 \\
\hline $\begin{array}{l}\text { Normalised } \\
\text { module } \Delta T\left({ }^{\circ} \mathrm{C}\right)\end{array}$ & 6.4 & 24.5 & 5.6 & 18.7 \\
\hline $\begin{array}{l}\text { Normalised } \\
\text { maximum cell } \\
\text { temperature } \\
\left({ }^{\circ} \mathrm{C}\right)\end{array}$ & 67.7 & 85.1 & 50.1 & 57.8 \\
\hline No. of Samples & 9 & 19 & 15 & 18 \\
\hline
\end{tabular}

between the average power degradation rate and the normalised module $\Delta \mathrm{T}$, For the data shown in table 7 . It can be concluded that from the above data that modules with Hot cells in Hot zone are degrading at high rates. Since, most of the climatic condition in Oman fall under Hot zone, The Hot cell issue is a major concern in PV Performance. The power degradation rate seems to correlate good with the mismatch between the cell temperatures in a module.

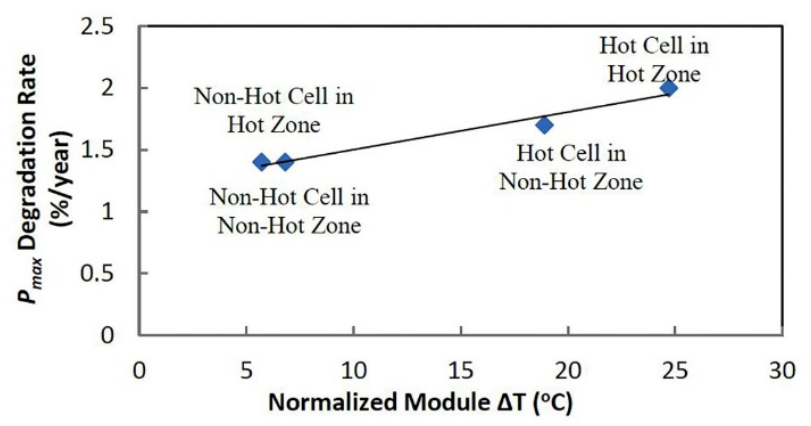

Figure 8. Correlation of Power degradation rate with the normalised module. $\Delta T$.

\section{Conclusion}

It is crucial to evaluating the efficiency of the PV modules in actual operating conditions on the field, taking into consideration that huge investments are being made in near future. The degradation rates play a vital role in predicting the reliability of PV systems under the influence of the local climatic zone and also to estimate the return on investments (ROI) for stakeholders. This case study has provided with significant results on the reliability of PV systems in Oman climatic factors. The visual degradation factors such as discolouration of the encapsulation and delamination of different PV technologies under the influence of different climatic factors are emphasized. Further, an empirical relation DDI (discoloration and delamination index) has been framed to correlate the degradation of $\left(\mathrm{I}_{\mathrm{sc}}\right)$ due to these visual effects. The results have shown that the $\left(\mathrm{I}_{\mathrm{sc}}\right)$ reduction was around $36 \%$ in very high DDI category and around $10 \%$ in low DDI category. It has also shown that the reduction in $\left(\mathrm{I}_{\mathrm{sc}}\right)$ was significant with the increase in DDI category which shows good correlation. The Overall mean power degradation rates of all modules are seen around $1.96 \% /$ year which is almost double the degradation rates seen in European countries which raises concerns about the reliability of PV systems in Oman. Furthermore, with regard to PV technology Multi-crystalline silicon has seen higher degradation rates (about 2.54\%/year) in hot-and-dry climatic zones While Mono-crystalline, silicon technology has shown higher degradation rates in the hot-and-humid zone. Thin film technology (CdTe) has shown better performance in both the zones and has fewer degradation rates than any other technology in the inspected modules.

Interconnect breakage points have been identified in the aged modules (especially). The effect of these breakage points has been evaluated using a relation SIB where again a correlation is performed with the series resistance of PV modules. It has observed that as the SIB increases the series series-resistance of the PV modules also increases. Furthermore, a correlation is performed with the output power degradation rates with the SIB which also shows that the increase in SIB causes an increase in degradation of output power $\left(P_{\max }\right)$. It was observed that the degradation rate was around $2.7 \%$ when the SIB was in the range of $41<$ and the lowest was about $1.26 \%$ when the SIB range is in between $0-10$. The degradation is further accelerated due to the presence of Hot-cells in the modules. Due to the presence of Hot-cells especially, the modules available in Hot zones have degraded faster than the modules in the Non-hot zone. It was also observed that the Multi-crystalline silicon technology was degrading much faster than the Mono-crystalline silicon technologies. This observation was much strengthened by the fact that the most of the Hot-cells observed are seen in the Multi-crystalline technology. The results become apparent from this case study may provide useful indicators for future deployments of PV systems in terms of location, technology type and diligence required for module technology selection in different climatic zones of Oman. It is very much essential to conduct period field case study in order to observe the reliability of PV systems under the local climatic influence.

\section{References}

[1] 'Access to Electricity - World Bank data', https://data.worldbank.org/indicator/, accessed 1 January 2018.

[2] 'Electricity Consumption-Energy data', https://yearbook.enerdata.net/electricity/electricitydomesticconsumption-data.html, accessed 1 January 2018.

[3] 'International Energy Agency', https://www.iea.org/statistics/statisticssearch/report/?year=2 $\underline{015 \& \text { country }=\text { MIDDLEEAST \& product }=\text { ElectricityandHeat }}$ , accessed 2 January 2018.

[4] OPWP., 'OPWP's 7-Year Statement (2016-2022)', (OPWP, 2016), PP. 4-5. 
[5] IRENA., 'IRENA's Sultanate of Oman Renewable energy assessment', (IRENA, 2016), PP. 42-43.

[6] Suleske, J. S., J. Kuitche, and G. Tamizh-Mani.: 'Performance degradation of grid-tied PV modules in a hotdry climatic condition', SPIE 8112.,2011, Reliability of Photovoltaic Cells, Modules, Components, and Systems IV. doi: $10.1117 / 12.894928$.

[7] Jordan, D. C., S. R. Kurtz, K. Van Sant, and J. Newmiller.: 'Compendium of photovoltaic degradation rates'. Prog. Photovoltaics Res. Appl. 2016, 24, pp 978-989.

[8] Jordan, D. C., and S. R. Kurtz.: 'Photovoltaic degradation rates-an analytical review'. Prog. Photovoltaics Res. Appl. 2013, 21: pp 12-29.

[9] Bora, B., O. S. Sastry, A. Kumar, and M. Bangar.: 'Performance modelling of three PV module technologies based on clearness index and air-mass using contour Map'. 42nd IEEE Photovoltaic Specialists Conference, New Orleans, 2015, pp. 1-4.

[10] Sharma, V., O. S. Sastry, A. Kumar, B. Bora, and S. Chandel. 'Degradation analysis of a-Si, HIT and mono c-Si solar photovoltaic technologies under outdoor conditions'. Energy, 2014, (72), pp 536-546.

[11] Mohamed s. honnurvali, Naren Gupta,: 'PV Electrical parameters degradation analysis -oman perspective', $8^{\text {th }}$ IEEE -IREC -Jordan, Mar 22-24, 2017, pp. 1-5.

[12] C. Packard, J. H. Wohlgemuth and S. R. Kurtz, 'Development of a visual inspection data collection tool for evaluation of fielded PV Module condition', NREL, Technical Report no. NREL/TP-5200-56154, Golden, Colorado, 2012.

[13] S. V. Spataru, D. Sera, P. Hecke, T. Kerekes and R. Teodorescu.: 'Fault identification in crystalline silicon PV modules by complementary analysis of the light and dark current-voltage characteristics', Progress in Photovoltaics: Research and Applications, 2015.

[14] Gueymard C. A., 'A Simple Model of the Atmospheric Radiative Transfer of Sunshine: Algorithms and Performance Assessment', Florida Solar Energy Center Technical Report No. FSEC-PF-270-95, Florida, 1995.

[15] G. Tamizhmani and J. Kuitche, 'Failure and Degradation Modes of PV Modules in a Hot Dry Climate: Results after 12 to 26 years of field exposure', in NREL PV Module Reliability Workshop, 2013.

[16] N. G. Dhere, N. S. Shiradkar and E. Schneller, 'Cell Line Checker Correlated to Infrared Thermography', in US PVMC Infrared Thermography Workshop, 2013.

[17] C. Buerhop, et al., 'Reliability of IR Imaging of PV Plants under operating conditions'. Solar Energfy Materials \& Solar Cells, vol. 107, 2012, pp. 154-164.
[18] International Energy agency (IEA), '16 Case Studies on the Deployment of Photovoltaic Technology in Developing Countries', IEA, Technical Report no. IEA-PVPS T9-07, 2003.

[19] J. Wohlgemuth, D. W. Cunningham, A. Nguyen,: 'Failure Modes of Crystalline Silicon Modules', in NREL PV Reliability Workshop, Denver, 2010.

[20] W. Holley and S. Argo.: 'Advanced EVA Based Encapsulants: Final Report', NREL, Technical Report no. NREL/TP-5200-56154, Golden, USA, 1998.

[21] G. Tamizhmani:, 'Climate dependent degradation rates based on nation-wide onsite I-V measurements', presented at 2016 PV Module Reliability Workshop, Lakewood, CO, 2016.

[22] R. Moreton, E. Lorenzo, J. Leloux and J.M.Carrillo, 'Dealing in Practice with Hot Spots': in 29th European Photovoltaic Solar Energy Conference and Exhibition, Amsterdam, 2014, pp. 2722-2727.

[23] J. Oh and G. TamizhMani, 'Temperature Testing and Analysis of PV modules per ANSI/UL 1703 and IEC 61730 standards': in 35th IEEE Photovoltaic Specialist Conference, Honolulu, 2010, pp. 984-988.

[24] C. Vodermayer, M. Mayer, T. Müller, M. Nieß, G. Wotruba, G. Becker, M. Zehner and J. Schumacher, 'First Results - Correlations between IR images and Electrical Behavior and Energy Yield of PV Modules': in $23^{\text {rd }}$ European Photovoltaic Specialists Conference, Valencia, Spain, 2008. 